\title{
REGRESSION ANALYSIS OF MILK PRODUCTION TRAITS IN SIMMENTAL COWS
}

\author{
M. D. Petrović ${ }^{1}$, V. Bogdanović ${ }^{2}$, M. M. Petrović ${ }^{3}$, S. Rakonjac ${ }^{1}$ \\ ${ }^{1}$ Faculty of Agronomy, Cacak, Republic of Serbia \\ ${ }^{2}$ Faculty of Agriculture, Belgrade-Zemun, Republic of Serbia \\ ${ }^{3}$ Institute for Animal Husbandry, Belgrade-Zemun, Republic of Serbia \\ Corresponding author: milunp@tfc.kg.ac.rs \\ Original scientific paper
}

Abstract: The relationship between milk production traits over whole lactations was evaluated across three generations of Simmental cows, i.e. between daughters, dams and grand dams, by a phenotypic regression analysis with whole lactation traits in the daughter generation being used as the dependent variables $\left(\mathrm{x}_{1}\right)$, and those in the dam and grand dam generations being used as the independent variables $\left(\mathrm{x}_{2}\right.$ and $\left.\mathrm{x}_{3}\right)$. The results were obtained from a sample of 1170 daughters and as many dams and grand dams. The significance of the partial regression coefficients $b_{2}$ and $b_{3}$ was separately evaluated by a t-test. An analysis of variance was used to estimate the significance of the simultaneous effect of the production traits of dams and grand dams on the milk production achieved in the daughter generation. The calculated value of the partial regression coefficients for the whole lactation production traits across three generations (grand dams, dams and daughters) and their statistical significances determined by the $t$ and $F$ tests, as well as the regression equations used, suggested that the effect of the grand dam generation on the milk production traits in granddaughters was substantially lower than the effect of dams. The calculated partial regression coefficients $\left(b_{2}\right.$ and $\left.b_{3}\right)$ were positive and statistically very significant $(\mathrm{P}<0.01)$, excepting the regression coefficients $b_{3}$ for lactation length and $b_{2}$ for milk fat content that were not statistically significant $(\mathrm{P}>0.05)$. A very significant change $(\mathrm{P}<0.01)$ was observed in all production traits in the daughter generation as simultaneously affected by the traits in the dam and grand dam generations

Key words: Simmental breed, production traits, generation, regression.

\section{Introduction}

The heritability of milk production traits of $25 \%$, continuous breeding for their improvement and the enhancement of raising conditions lead to both yield increases and the relationship between the traits across generations. However, the 
relevant literature on the relationship between production traits across generations is rather scarce.

Yield increases across generations as being facilitated by continuous breeding work and improving raising conditions, primarily nutrition and care, have been reported by international authors (Rycken, 1996, 1997, 1998), whereas Serbian authors observe declining trends in milk and milk fat yields across generations in imported breeding heifers as being primarily induced by poorer raising conditions and earlier exposure to breeding as compared to the situation in Western European developed countries (Germany, Switzerland, Austria) from which they were imported (Bogdanovic et al., 2008; Lazarevic et al., 1984; Nenadovic et al., 1986; Petrovic M.M.,1997, 2008; Petrovic D.M., 2008; Petrovic D.M. et al., 2009; Pantelic et al., 2011).

The above suggests that more substantial increases in milk performance in Serbian spotted Simmental dairy cattle can be achieved through breeding work, by using superior sire bulls and via timely exposure to breeding along with continuous improvements in raising conditions as compared to the imported Simmental breeding heifers.

In their study on the milk production potential and performance across generations of Simmental cows in Poland, Tarkovski and Trautman (1997) attributed the increase in milk production across generations to the use of Simmental sires imported from Germany, Austria and Switzerland.

Analysing the milk performance of Simmental cows in Switzerland during 1995-1996, 1996-1997 and 1997-1998, Rycken (1996, 1997, 1998) indicated that milk performance improvement across generations was a result of improvements in both the genetic potential of the bull sires and the raising conditions used.

\section{Materials and Methods}

The relationship between milk production traits over whole lactations was evaluated across three generations of Simmental cows, i.e. between daughters, dams and grand dams, by a phenotypic regression analysis with whole lactation traits in the daughter generation being used as the dependent variables $\left(\mathrm{x}_{1}\right)$, and those in the dam and grand dam generations being used as the independent variables $\left(\mathrm{x}_{2}\right.$ and $\left.\mathrm{x}_{3}\right)$. The results were obtained from a sample of 1170 daughters and as many dams and grand dams.

Milk production traits of whole lactations, as assessed by regression analysis, included the following:

- lactation length (WLL), (days),

- milk yield over whole lactations (MYWL), (kg),

- milk fat content over whole lactations (MFCWL), (\%),

- milk fat yield over whole lactations (MFYWL), (kg) and 
- 4\% FCM yield over whole lactations (4\%FCMWL), (kg).

The regression analysis employed involved the calculation of the $a_{1.23}$ parameters (a) and the partial regression coefficients $b_{12.3}\left(b_{2}\right)$ and $b_{13.2}\left(b_{3}\right)$ using the following general linear multiple regression model involving three variables:

$$
\hat{X}_{1}=a_{1.23}+b_{12.3} X_{2}+b_{13.2} X_{3} \quad \text { or } \quad \hat{X}_{1}=a+b_{2} X_{2}+b_{3} X_{3}
$$

The partial regression coefficients $b_{12.3}\left(b_{2}\right)$ and $b_{13.2}\left(b_{3}\right)$ were calculated using the following system of equations:

$$
\begin{aligned}
& \sum_{i=1}^{n} x_{1 i} x_{2 i}=b_{2} \sum_{i=1}^{n} x_{2 i}^{2}+b_{3} \sum_{i=1}^{n} x_{2 i} x_{3 i} \\
& \sum_{i=1}^{n} x_{1 i} x_{3 i}=b_{2} \sum_{i=1}^{n} x_{2 i} x_{3 i}+b_{3} \sum_{i=1}^{n} x_{3 i}^{2}
\end{aligned}
$$

Unknown partial regression coefficients $\left(b_{2}\right.$ and $\left.b_{3}\right)$ were computed using determinants:

$$
b_{2}=\frac{D_{b_{2}}}{D} \text { and } b_{3}=\frac{D_{b_{3}}}{D}
$$

The third constant of linear multiple regression a, as the average initial level, was calculated using the formula:

$$
a=\bar{X}_{1}-b_{2} \bar{X}_{2}-b_{3} \bar{X}_{3}
$$

The significance of the partial regression coefficients $b_{2}$ and $b_{3}$ was tested using the following t-test:

$$
\begin{array}{cc}
\text { Ho: } \mathrm{b}_{2}=0 & \text { Ho: } \mathrm{b}_{3}=0 \\
t=\frac{\left|b_{2}\right|}{S_{b_{2}}} & t=\frac{\left|b_{3}\right|}{S_{b_{3}}}
\end{array}
$$

Where: 
$\mathrm{X}_{1}, \mathrm{X}_{2}, \mathrm{X}_{3}$ - value of whole lactation variable traits of daughters, dams and grand dams,

$\mathrm{a}_{1.23}$ or a - constant value, representing the average initial level of whole lactation traits,

$b_{12.3}$ or $b_{2}$ and $b_{13.2}$ or $b_{3}$ - partial regression coefficients,

$\sum_{i=1}^{n} x_{1 i} x_{2 i}, \sum_{i=1}^{n} x_{2 i}^{2}, \sum_{i=1}^{n} x_{2 i} x_{3 i}, \sum_{i=1}^{n} x_{1 i} x_{3 i}, \sum_{i=1}^{n} x_{2 i} x_{3 i}, \sum_{i=1}^{n} x_{3 i}^{2}$ - corrected sums of

squares and intermediates in three generations of cows,

D, $D_{b_{2}}, D_{b_{3}}$ - determinants,

$S_{b_{2}}, S_{b_{3}}$ - standard errors of the regression coefficients.

The hypothesis that the regression coefficients $b_{2}$ and $b_{3}$ were equal to unity $\left(\mathrm{Ho}: \mathrm{b}_{2}=\mathrm{b}_{3}=0\right)$ was checked by the analysis of variance method using the Statistica statistical software for Windows Release 5.0. This analysis was used to determine $F_{\text {exp }}$ values i.e. the significance of the simultaneous effect of production traits of dams and grand dams on the level of production achieved in daughters.

\section{Results and Discussion}

Regression analysis was employed to calculate the parameters $\mathrm{a}_{1.23}$ (a) and partial regression coefficients $b_{12.3}\left(b_{2}\right)$ and $b_{13.2}\left(b_{3}\right)$. The significance of the coefficients was evaluated by a t-test (Table 1). An analysis of variance ( $F$ test) was used to estimate the significance of the simultaneous effect of the production traits of dams and grand dams on the traits of daughters. The results obtained are given in Tables 2 through 5 .

Table 1. Regression analysis of whole lactation traits between three generation of cows (daugher, dam and grand dam)

\begin{tabular}{|l|c|c|c|c|}
\hline \multirow{2}{*}{ Traits } & \multirow{2}{*}{$\begin{array}{c}\text { Parameter } \\
\mathrm{a}_{1.23}\end{array}$} & \multicolumn{2}{|c|}{ Partial regression coefficients } & \multirow{2}{*}{ Multiple regression equation } \\
\cline { 3 - 4 } & $\mathrm{b}_{12.3}\left(\mathrm{~b}_{2}\right)$ & $\mathrm{b}_{13.2}\left(\mathrm{~b}_{3}\right)$ & \\
\hline WLL, days & $244.156^{* *}$ & $0.135^{* *}$ & $0.056^{\mathrm{ns}}$ & $\hat{X}_{1}=244.156+0.135 \mathrm{X}_{2}+0.056 \mathrm{X}_{3}$ \\
\hline MYWL, kg & $2856.296^{* *}$ & $0.193^{* *}$ & $0.073^{* *}$ & $\hat{X}_{1}=2856.296+0.193 \mathrm{X}_{2}+0.073 \mathrm{X}_{3}$ \\
\hline MFCWL, kg & $121.050^{* *}$ & $0.146^{* *}$ & $0.044^{*}$ & $\hat{X}_{1}=121.050+0.146 \mathrm{X}_{2}+0.044 \mathrm{X}_{3}$ \\
\hline MFYWL, \% & $2.973^{* *}$ & $0.0003^{\mathrm{ns}}$ & $0.222^{* *}$ & $\hat{X}_{1}=2.973+0.0003 \mathrm{X}_{2}+0.222 \mathrm{X}_{3}$ \\
\hline 4\%FCMWL, kg & $2955.519^{* *}$ & $0.168^{* *}$ & $0.054^{* *}$ & $\hat{X}_{1}=2955.519+0.168 \mathrm{X}_{2}+0.054 \mathrm{X}_{3}$ \\
\hline
\end{tabular}

N.S. - P $>0.05 ; *-\mathrm{P}<0.05 ; \quad * *-\mathrm{P}<0.01 ;$

lactation length (WLL), milk yield over whole lactations (MYWL), milk fat content over whole lactations (MFCWL), milk fat yield over whole lactations (MFYWL) and 4\% FCM yield over whole lactations (4\%FCMWL). 
The calculated coefficient $b_{2}$, as shown in Table 1 , indicates that a one-day increase in whole lactation length in dams resulted in a 0.135 -day increase in lactation length in daughters with the lactation length in grand dams remaining unchanged. The partial regression coefficient $b_{3}$ shows that the whole lactation length in daughters increased by 0.0056 days with a one-day increase in lactation length in grand dams, with the lactation length in dams remaining unchanged.

The analysis of the significance of the partial regression coefficients, as determined by the t-test, reveals that the lactation length in daughters was statistically very significantly $(\mathrm{P}<0.01)$ affected by whole lactation length in dams and nonsignificantly $(\mathrm{P}>0.05)$ by whole lactation length in grand dams.

The analysis of variance (Table 2) suggests very significant changes $(\mathrm{P}<0.01)$ in whole lactation length in daughters as affected simultaneously by lactation length in dams and grand dams $\left(\mathrm{F}_{\mathrm{exp}}=14.77797^{* *}\right)$.

Table 2. Analysis of variance on the simultaneous effect of whole lactation length in dams and grand dams on the expression of the trait in daughters

\begin{tabular}{|l|c|c|c|c|}
\hline Sources of variation & $\begin{array}{c}\text { Sums of squares } \\
(\mathrm{SS})\end{array}$ & $\begin{array}{c}\text { Degrees of } \\
\text { freedom (df) }\end{array}$ & $\begin{array}{c}\text { Mean squares } \\
(\mathrm{MS}(\mathrm{SS} / \mathrm{df}))\end{array}$ & $\mathrm{F}_{\exp }$ \\
\hline Regression & 104012 & 2 & 52006.02 & $14.77797^{* *}$ \\
\hline Error & 12352250 & 3510 & 3519.16 & \\
\hline Total & 12456262 & & & \\
\hline \multicolumn{2}{r}{ N.S. - P $>0.05 ; *-\mathrm{P}<0.05 ; * *-\mathrm{P}<0.01 ; * * *-\mathrm{P}<0.001 ;$} \\
\end{tabular}

The increase of 0.193 and $0.168 \mathrm{~kg}$ in milk yield and 4\% FCM yield, respectively, in daughters was associated with each kilogram of the yield increase in dams, with the yield in grand dams remaining unchanged (Table 1). The milk yield in daughters was substantially less affected by the milk performance of grand dams. The one-kilogram increase in milk and 4\% FCM yields in grand dams induced an increase of 0.073 and $0.054 \mathrm{~kg}$ in the respective yields in daughters, with the milk performance of dams remaining unchanged.

The significance of the partial regression coefficients in milk yield and $4 \%$ FCM yield, as determined by the t-test, was very high $(\mathrm{P}<0.01)$.

Very significant changes $(\mathrm{P}<0.01)$ in both milk yield and $4 \% \mathrm{FCM}$ yield in daughters were also induced by the simultaneous effect of milk and 4\% FCM yields in dams and grand dams $\left(\mathrm{F}_{\exp }=58.81113^{* *}\right.$ and $\left.\mathrm{F}_{\mathrm{exp}}=41.96612^{* *}\right)$, as suggested by the analysis of variance presented in tables 3 and 4 . 
Table 3. Analysis of variance on the simultaneous effect of whole lactation milk production traits in dams and grand dams on the milk performance of daughters

\begin{tabular}{|l|c|c|c|c|}
\hline Sources of variation & $\begin{array}{c}\text { Sums of squares } \\
(\mathrm{SS})\end{array}$ & $\begin{array}{c}\text { Degrees of } \\
\text { freedom }(\mathrm{df})\end{array}$ & $\begin{array}{c}\text { Mean squares } \\
(\mathrm{MS}(\mathrm{SS} / \mathrm{df}))\end{array}$ & $\mathrm{F}_{\text {exp }}$ \\
\hline Regression & $1.409118 \mathrm{E}+08$ & 2 & 70455892 & $58.81113^{* *}$ \\
\hline Error & $4.204989 \mathrm{E}+09$ & 3510 & 1198003 & \\
\hline Total & $4.345901 \mathrm{E}+09$ & & & \\
\hline
\end{tabular}

Table 4. Analysis of variance on the simultaneous effect of the 4\% FCM yield over whole lactations in dams and grand dams on the corresponding yield in daughters

\begin{tabular}{|l|c|c|c|c|}
\hline Sources of variation & $\begin{array}{c}\text { Sums of squares } \\
(\mathrm{SS})\end{array}$ & $\begin{array}{c}\text { Degrees of } \\
\text { freedom (df) }\end{array}$ & $\begin{array}{c}\text { Mean squares } \\
(\mathrm{MS}(\mathrm{SS} / \mathrm{df}))\end{array}$ & $\mathrm{F}_{\mathrm{exp}}$ \\
\hline Regression & $9.273446 \mathrm{E}+07$ & 2 & 46367231 & $41.96612^{* *}$ \\
\hline Error & $3.878104 \mathrm{E}+09$ & 3510 & 1104873 & \\
\hline Total & $3.970839 \mathrm{E}+09$ & & & \\
\hline
\end{tabular}

The milk fat yield in daughters was very significantly $(\mathrm{P}<0.01)$ and significantly $(\mathrm{P}<0.05)$ affected by the yield in dams and grand dams. Namely, the milk fat yield in daughters showed a $0.146 \mathrm{~kg}$ increase as a result of a $1 \mathrm{~kg}$ increase in dams, with the yield of grand dams remaining unchanged $\left(b_{2}=0.146\right)$. The $1 \mathrm{~kg}$ increase in milk fat yield in grand dams induced a $0.044 \mathrm{~kg}$ increase in daughters with the yield in dams remaining unchanged $\left(b_{3}=0.044\right)$.

The analysis of variance given in Table 5 suggests very significant changes $(\mathrm{P}<0.01)$ in the milk fat yield of daughters as simultaneously affected by the milk fat yield of both dams and grand dams $\left(\mathrm{F}_{\exp }=31,50756^{* *}\right)$.

Table 5. Analysis of variance on the simultaneous effect of milk fat yield over whole lactations in dams and grand dams on the milk fat yield in daughters

\begin{tabular}{|l|c|c|c|c|}
\hline Sources of variation & $\begin{array}{c}\text { Sums of squares } \\
(\mathrm{SS})\end{array}$ & $\begin{array}{c}\text { Degrees of } \\
\text { freedom }(\mathrm{df})\end{array}$ & $\begin{array}{c}\text { Mean squares } \\
(\mathrm{MS}(\mathrm{SS} / \mathrm{df}))\end{array}$ & $\mathrm{F}_{\exp }$ \\
\hline Regression & 106358 & 2 & 53178.91 & $31.50756^{* *}$ \\
\hline Error & 5924228 & 3510 & 1687.81 & \\
\hline Total & 6030586 & & & \\
\hline
\end{tabular}

The milk fat content in daughters increased $0.0003 \%$ with each percent of increase in dams, with the content in grand dams remaining unchanged. The effect was not statistically significant $(\mathrm{P}>0.05)$. Conversely, the effect of the milk fat content in grand dams on that in daughters, with the content in dams remaining unchanged, was 
highly significant $(\mathrm{P}<0.01)$. Moreover, the $1 \%$ increase in the milk fat content in grand dams resulted in a $0.222 \%$ increase in daughters.

Table 6. Analysis of variance on the simultaneous effect of milk fact content over whole lactations in dams and grand dams on the content in daughters

\begin{tabular}{|l|c|c|c|c|}
\hline Sources of variation & $\begin{array}{c}\text { Sums of squares } \\
(\mathrm{SS})\end{array}$ & $\begin{array}{c}\text { Degrees of } \\
\text { freedom (df) }\end{array}$ & $\begin{array}{c}\text { Mean squares } \\
(\mathrm{MS}(\mathrm{SS} / \mathrm{df}))\end{array}$ & $\mathrm{F}_{\text {exp }}$ \\
\hline Regression & 5.41486 & 2 & 2.707431 & $117.7837^{* *}$ \\
\hline Error & 80.68248 & 3510 & 0.022986 & \\
\hline Total & 86.09735 & & & \\
\hline \multicolumn{4}{|l}{ N.S. $-\mathrm{P}>0.05 ; *-\mathrm{P}<0.05 ; * *-\mathrm{P}<0.01 ; * * *-\mathrm{P}<0.001 ;$} \\
\end{tabular}

A statistically very significant $(\mathrm{P}<0.01)$ change $\left(\mathrm{F}_{\text {exp }}=117.7837^{* *}\right)$ was observed in the milk fat content in daughters as induced by the simultaneous effect of the milk fat content in dams and grand dams, as suggested by the analysis of variance results given in Table 6 .

\section{Conclusion}

The calculated value of the partial regression coefficients for the whole lactation production traits across three generations (grand dams, dams and daughters) and their statistical significances determined by the $\mathrm{t}$ and $\mathrm{F}$ tests, as well as the regression equations used, suggest the following:

- the effect of the grand dam generation on the milk production traits in granddaughters was substantially lower than the effect of dams;

- the calculated partial regression coefficients $\left(b_{2}\right.$ and $\left.b_{3}\right)$ were positive and statistically very significant $(\mathrm{P}<0.01)$, excepting the regression coefficients $b_{3}$ for lactation length and $b_{2}$ for milk fat content that were not statistically significant $(\mathrm{P}>0.05)$.

- a very significant change $(\mathrm{P}<0.01)$ was observed in all production traits in the daughter generation as simultaneously affected by the traits in the dam and grand dam generations

\section{Acknowledgment}

Research was financed by the Ministry of Education and Science, Republic of Serbia, project TR 31086. 


\title{
Korelaciona analiza povezanosti proizvodnih osobina kroz tri generacije krava simentalske rase
}

\author{
M. D. Petrović, V. Bogdanović, M. M. Petrović, S. Rakonjac
}

\section{Rezime}

Povezanost osobina mlečnosti u punim laktacijama analizirana je između tri generacije krava simentalske rase, odnosno između kćerki, majki i baba, fenotipskom regresionom analizom u uslovima kada su osobine punih laktacija u generaciji kćerki posmatrane kao zavisno $\left(x_{1}\right)$, a osobine punih laktacija u generaciji majki i baba kao nezavisno promenljive $\left(x_{2} i x_{3}\right)$. Rezultati su dobijeni na uzorku od po 1170 kćerki, majki i baba.

Pojedinačno ispitivanje značajnosti delimičnih regresionih koeficijenata $b_{2}$ $i b_{3}$ izvršeno je t-testom, a analizom značajnosti istovremenog uticaja proizvodnih osobina majki i baba na ostvarenu proizvodnju kod kćerki izvršena je metodom analize varijanse.

$\mathrm{Na}$ osnovu izračunate vrednosti delimičnih regresionih koeficijenata za proizvodne osobine celih laktacija kroz tri generacije (babe, majke i kćerke) i njihove statističke značajnosti određene t i $F$ testom, kao i jednačina regresije konstatovano je da je uticaj generacije baba na proizvodnju unuka znatno manji u odnosu na uticaj kojeg imaju majke. Svi izračunati delimični koeficijenti regresije $\left(b_{2} i b_{3}\right)$ bili su pozitivni i statistički vrlo značajni $(\mathrm{P}<0.01)$, izuzimajući koeficijent regresije $b_{3}$ kod trajanja laktacije i $b_{2}$ kod sadržaja mlečne masti koji nisu bili statistički značajni ( $\mathrm{P}>0.05)$. Značajnost promena svih posmatranih proizvodnih osobina u generaciji kćerki pri istovremenom uticaju tih osobina iz generacije majki i baba bila je vrlo visoka $(\mathrm{P}<0.01)$.

\section{References}

BOGDANOVIC V., DJEDOVIC R., STELJA S., PERISIC P., PETROVIC M.D., DJURDJEVIC R. (2008): Simulacija genetskog napretka u nukleus zapatu simentalskih goveda i implikacije na odgajivacki program. Biotechnology in Animal Husbandry, 24, spec. issue, 61-70.

LAZAREVIC R., MILOJIC M., LATINOVIC D. (1984): Nasledjivanje mlecnosti u populaciji crno belog goveceta. Stocarstvo, 3-4, 101-106. Zagreb.

NENADOVIC M., MIJIC D., VUCINIC J. (1986): Nasledjivanje osobina dugovecnosti i proizvodnje mleka u populaciji goveda domace sarene rase. Savremena poljoprivreda, 34, 11-12, 485-496. 
PANTELIC V., PLAVSIC M., TRIVUNOVIC S., ALEKSIC S., SRETENOVIC LJ., OSTOJIC-ANDRIC D., NIKSIC D. (2011): The evaluation of breeding value of Simmental bulls for milk performance in Serbia. Biotechnology in Animal Husbandry, 27, 2, 127-135.

PETROVIC D.M. (2008): Fenotipska varijabilnost proizvodnih i reproduktivnih osobina tri generacije krava simentalske rase. Doktorska disertacija. Poljoprivredni fakultet, Beograd- Zemun.

PETROVIC D.M., SKALICKI Z., PETROVIC M.M., BOGDANOVIC V. (2009): The efect of systematic factors on milk yield in Simmental cows over complete lactations. Biotechnology in Animal Husbandry, 25, 1-2, 61-71.

PETROVIC M.M., LAZAREVIC R., LAZAREVIC LJ., ALEKSIC S., MISCEVIC B., PERKOVIC S. (1997): Proizvodni efekti selekcije aktivne populacije simentalskih goveda u Srbiji. Biotehnologija u stocarstvu, 13, 3-4, 57-64.

PETROVIC M.M., SRETENOVIC LJ., ALEKSIC S., PANTELIC V., NOVAKOVIC Z., PERISIC P., PETROVIC M.D. (2009): Investigation of the heritability of phenotypes of fertility and milk performance of Simmental cattle breed in Serbia. Biotechnology in Animal Husbandry, 25, 5-6, 285-292.

RYCHEN M. (1996): Results of milk recording of Simmental in Switzerland in 1995-96. Schweizer-Fleckvieh, 1996, No. 7, 56-73.

RYCHEN M. (1997): Results of milk recording in Simmental cows in 1996-97. Milk yield and milk protein yield are still increasing. Schweizer-Fleckvieh, 1997, No. 7, 26-41.

RYCHEN M. (1998): Results of milk yields of Swiss Simmental during the year 1997/97. Important increases in milk yield. Schweizer-Fleckvieh, 1998, No. 7, $28-41$. Statsoft Inc. Statistica For Windows, Version 5.0, Computer program manual. Tulsa,: StatSoft Jnc., 1995.

TARKOWSKI J., TRAUTMAN J. (1997): The performance and fertility of Simmental cows at the PHOZ Brzozow in relation to their genetic potential. Annales Universitatis Mariae Curie Sklodowska. Sectio EE Zootechnica, 1997, 15, $15-22 ; 8$ ref. 